\title{
The Problem of Russia's Declining Influence in the Former Soviet Union: Why Are the CIS Countries Drifting Toward Multilateralism? ${ }^{1}$
}

\author{
O. Petrovich-Belkin, S. Bokeriya, A. Eremin
}

Oleg Petrovich-Belkin - PhD, Senior Lecturer, Department of Theory and History of International Relations, Peoples' Friendship University of Russia; 10/2 Miklukho-Maklaya Str., Moscow, 117198, Russian Federation; E-mail: petrovioleg@yandex.ru

Svetlana Bokeriya - PhD, Associate Professor, Department of Theory and History of International Relations, Peoples' Friendship University of Russia; 10/2 Miklukho-Maklaya Str., Moscow, 117198, Russian Federation; E-mail: petrovsvet@yandex.ru

Arkady Eremin - PhD, Senior Lecturer, Department of Theory and History of International Relations, Peoples' Friendship University of Russia; 10/2 Miklukho-Maklaya Str., Moscow, 117198, Russian Federation; E-mail: eremin_aa@rudn.university

\begin{abstract}
Since the collapse of the Soviet Union, the problem of Russia's relations with the countries of the former USSR has traditionally been the focus of attention of both the academic and the expert community. This issue becomes especially urgent in the context of significant changes in world politics caused by the rapid deterioration of relations between Russia and the western world following the escalation of the Ukrainian crisis. This article identifies the key economic, political and social factors having a negative impact on the current dynamics of relations between the Russian Federation and the countries of the Commonwealth of Independent States (CIS) and thereby gradually decreasing Russia's influence in the former Soviet Union.

The article is structured around three groups of factors - objective, ambivalent and subjective - which impede the growth of Russia's influence in the former Soviet Union. Objective factors are related to economic and political issues, ambivalent (mixed) factors are those of sociocultural and historical nature and subjective factors are predominantly psychological. Based on an extensive analysis of relevant material, the authors conclude that the CIS countries refuse to follow the pro-Russian path not only (and in some cases not so much) due to the objective need of the post-Soviet countries for diversified political, trading and economic ties, but also (and rather) for several subjective, social and cultural, political and psychological factors considered in detail below. An important conclusion of this research is that most subjective factors negatively affecting the efficiency of Russia's policy in the former Soviet Union can be potentially and significantly minimized in a relatively short term. Objective factors, especially those concerning Russia's declining role in the world economy and its reduced trade volumes with the CIS countries, on the contrary, are of a rather long-term nature and therefore it may take a considerable amount of time to adjust the current dynamics.
\end{abstract}

Key words: foreign policy; multilateralism; CIS; former Soviet Union; Russia; political influence

For citation: Petrovich-Belkin O., Bokeriya S., Eremin A. (2019) The Problem of Russia's Declining Influence in the Former Soviet Union: Why Are the CIS Countries Drifting Toward Multilateralism? International Organisations Research Journal, vol. 14, no 1, pp. 94-112 (in English). DOI: 10.17323/1996-7845-2019-01-06

${ }^{1}$ The editorial board received the article in May 2018. 


\section{Introduction: The Purpose and Objectives of the Research}

The need for a comprehensive study of the specifics of Russia's foreign policy carried out in the former Soviet Union is conditioned by both the rank that the region holds in the structure of Russia's foreign policy interests, reflected in several conceptual documents of the country (in particular, the 2016 Foreign Policy Concept of the Russian Federation $^{2}$ ), and the trends that are increasingly evident over the past decades in the relations between Russia and the countries of the former Soviet Union. There are at least three specific features characteristic of Russia's interaction with these countries which have led to the gradual decline in Russia's influence.

First, a variety of political forces in the Commonwealth of Independent States (CIS), previously focused on Russia's foreign policy course, are now striving to employ an increasingly diversified, multilateral approach, thereby de jure or de facto distancing themselves from close coordination of their own foreign policy interests with those of Russia. Second, this trend results in a significant decrease in Russia's foreign policy efficiency in the former Soviet Union. To a large extent, this is because quite often Russia's assumption that the national elites of the CIS countries are natively loyal and pro-Russian is not completely accurate. Third, foreign policy divergence between Russia and the countries of the former Soviet Union means that the relations between Russia and several post-Soviet countries have lost their former privileged status, having a negative impact on political, economic, cultural and humanitarian relations between them.

The objective of this research is to identify the key economic, political and social factors adversely affecting the current dynamics of relations between the Russian Federation and the CIS countries which are causing a gradual decline in Russia's influence. In particular, the combination of the above factors often results in a sometimes quite noticeable cooling of Russia's relations with individual countries of the former Soviet Union (for example, occasionally, with Azerbaijan, Uzbekistan, Tajikistan and Turkmenistan). In exceptional cases it even results in the emergence and subsequent escalation of a political conflict (involving Ukraine, Georgia and Moldova). Moreover, to a certain extent a similar trend can be observed in the larger international arena, involving the western states with whom the quality of Russia's relations are currently on the downturn. This research analyzes the factors causing the gradual drift of the proRussian forces in the former Soviet Union toward multilateralism.

This requires first, identification and analysis of factors causing a decline in Russia's influence; second, assessment of the objective, ambivalent and subjective subgroups of factors; third, consideration of the importance of the deterioration of relations between Russia and the West between 2014-2018 as a factor; and fourth, analysis of Russia’s ac-

2 "The foreign policy priorities of the Russian Federation include developing bilateral and multilateral cooperation with member States of the Commonwealth of Independent States (CIS) and further strengthening integration structures within the CIS involving Russia" [Ministry of Foreign Affairs of the Russian Federation, 2016, Clause 49]. 
tivities in the CIS, the Eurasian Economic Union (EAEU) and the Collective Security Treaty Organization (CSTO) on the understanding that Moscow's desire to intensify integration in the former Soviet Union was a response to its reduced influence in the region.

\section{Key Definitions, Methodology and Historiography}

To begin, it is necessary to clarify terms such as the pro-Russian focus (pro-Russian forces) and multilateralism (multilateral approach).

When speaking about the pro-Russian focus of certain forces in the former Soviet Union, the authors are referring to the objective or subjective viewpoint of certain political leaders or members of the national elites of the CIS countries, directly interested in building close, privileged relations with Russia in political, economic, social, cultural, humanitarian and other spheres. Accordingly, the authors use the term multilateralism (or multilateral approach) as a kind of antithesis, meaning the foreign policy strategy and actions of certain forces in the former Soviet Union aimed at diversifying the political relations of the country in the international arena, as well as forming stable interstate relations with the widest range of international actors, which can be objectively proven or subjectively perceived as a rejection of privileged relations with Russia.

The research methodology employed focuses on both objective and the subjective components underlying the drift of pro-Russian forces toward multilateralism. In this connection, the authors single out five groups of factors (economic; political; sociocultural and historical; political and psychological), which in turn are divided into three broad subgroups: objective (economic and political), ambivalent (historical, social and cultural) and subjective (political and psychological) factors.

The authors use quantitative and content analysis to compare the economic indicators of gross domestic product (GDP) growth and trade dynamics between Russia and the countries of the former Soviet Union and employ event analysis to consider the issue of several CIS states shifting from Cyrillic to Latin. A systemic approach and analysis of the process of foreign policy decision-making was used to evaluate subjective political and psychological factors affecting the relations between Russia and individual post-Soviet countries.

In recent years, the problem considered in this article has been reflected in the work of several Russian and foreign authors. In particular, in the Russian historiography, it has been considered by researchers including D. Degterev, I. Vasilyuk and V. Baum [2018], K.P. Kurylev [2016a, 2016b], V. Lapkin and V. Pantin [2016], N.G. Galoyan [2015] and others. In this context, it is worth mentioning the collective English monograph, titled Russia and East Central Europe after the Cold War, under the scientific editorship of A. Zagorsky [2015], a Russian researcher. The problems of trade and economic relations between Russia and the countries of the former Soviet Union have been addressed in the work of authors such as S.P. Bazyleva and Y.F. Chernenko 
[2016], S.N. Fedorchenko [2017] and V. Obolensky [2017]. Cultural and humanitarian, as well as ideological, determinants of Russia's foreign policy in its historical retrospect were examined in detail by R.A. Arslanov et al. [2017]. As for the foreign historiography, for objective reasons the relevant works are not so numerous. In this context, the most topical ones are the scientific works of such authors such as R. Menon and E. Rumer [2014], C. Descalzi [2011] and T. Gomart [2006].

\section{Economic Factors Underlying Russia's Declining Influence in the Former Soviet Union}

One of the main economic factors determining Russia's gradual loss of political influence in the former Soviet Union is the general decrease over the last 25 years in Russia's role in the world economy and international commodity turnover. In particular, according to the World Bank, while in 1991 the Russian Federation (RSFSR) had a purchasing power parity GDP share totaling 3.9\% of the global value, by 2008 it dropped to $3.4 \%$ and by the end of 2017 it declined further to 2.8\% [World Bank, n.d.]. Undoubtedly, this decline in Russia's economic opportunities reduced the efficiency of its policy in the former Soviet Union. This can be explained in several ways. First, there is an ever-increasing deficit in the economic (and consequently, political) instruments of Russia's influence in the CIS region. Second, because the attractiveness of a foreign policy course aimed at building close trade and economic ties with Russia is generally declining for a number of post-Soviet countries, they are gradually refocusing their policies toward multilateral economic cooperation with dynamically developing actors external to the region. For instance, they are shifting toward cooperation with China (which is primarily relevant for the countries of Central Asia). Third, the gradual decline in Russia's role in the world economy has had the most negative impact on Russia's trade turnover with the post-Soviet countries, with a particularly pronounced decline between Russia and several CIS countries in the period after 2014, including a sharp aggravation of Russia's economic problems due to the consequences of the Ukrainian crisis and the introduction of western sanctions. For example, for the period of 2014-2016, the aggregate trade turnover decreased by 23\% between Russia and Belarus (from $\$ 30.5$ billion to $\$ 23.5$ billion); by $37 \%$ with Kazakhstan (from $\$ 20.8$ billion to $\$ 13.03$ billion); by $32 \%$ with Uzbekistan (from $\$ 3.96$ billion to $\$ 2.7$ billion); by $4 \%$ with Armenia (from $\$ 1.4$ billion to $\$ 1.34$ billion); by $51 \%$ with Azerbaijan (from $\$ 3.96$ billion to $\$ 1.95$ billion); and by $63 \%$ with Ukraine (from $\$ 27.8$ billion to $\$ 10.2$ billion) [Foreign Trade of Russia, 2017].

The situation over the past few years has been characterized by a tangible decrease in the intensity of certain trade and economic ties between Russia and the majority of the post-Soviet countries, and by the ongoing process of Eurasian integration. The development of the EAEU has unfortunately not slowed this process by a visible degree. The result of these dynamics is the disappearance of the "economic airbag" which 
had previously smoothed out some of the contradictions emerging from time to time between Russia and individual CIS countries, and which had acted as a solid basis for building a constructive political dialogue on the widest possible range of matters. In this context, the situation with Ukraine is particularly symptomatic, causing the aggravation of foreign policy contradictions between the countries which leads to a decrease in the intensity of trade and economic interaction between them and, as a consequence, to a sharp reduction in their trade turnover. In turn, the breakup of trade and economic ties results in the disappearance of a limiting factor which, to a certain extent, would prevent a further escalation of political tensions between the countries.

The decline in trade turnover between Russia and the countries of the former Soviet Union entails a gradual decline in the influence of pro-Russian members of the CIS countries' political elites, as well as the related special interest groups in the economy (entrepreneurs, financiers, etc.) which are objectively interested in maintaining close ties with Russia in both economic and political spheres. This naturally makes the countries in question turn to an alternative foreign policy direction based on a multilateral course.

And, finally, another important economic factor contributing to the decline of Russia's influence in the former Soviet Union is the objective interest of the CIS countries in developing trade and economic interaction with the widest range of extraregional actors, for instance, with the countries of the West. Earlier, in the absence of a conflict between Russia and the western world and the existence of relatively close economic, cultural and humanitarian links between them, such aspirations did not and could not entail any serious financial or reputational losses for Russia. However, after the introduction of western sanctions and a sharp aggravation of foreign policy contradictions generated primarily by the Ukrainian and the Syrian crises, individual CIS countries (such as Ukraine, Moldova and to a lesser extent, Belarus) are facing a dilemma: they must choose between Russia or the West - there is no third option. Earlier, for the post-Soviet countries it was just a matter of diversifying the economic course and establishing stable trade relations with the widest possible range of external actors. Today, it is increasingly evident that the countries in question have to play a zero-sum game, being forced to make a choice in favour of one of the two sides of a global confrontation. This choice inevitably deteriorates the relations (possibly even resulting in a conflict) with the country losing in this competition. Undoubtedly, such a dilemma, faced by a multitude of CIS countries (and, above all, by those countries that already enjoy long-standing trade relations with the western world) cannot help but deteriorate Russia's economic and, consequently, political positions in the former Soviet Union.

At the same time, the significance of these economic factors reducing Russia's influence in the CIS region should in no way be overemphasized. For instance, this trend does not fit the situation of the Republic of Belarus which has traditionally maintained a high level of trade and economic ties with Russia. Minsk is, nevertheless, quite 
independent from Moscow in the way it conducts its foreign policy, which shows that the above methodology should be employed with a considerable degree of caution. It is also necessary to consider the important fact that the indicators of economic trade turnover between Russia and the CIS countries are quoted in US dollars, and therefore the relevant statistical data should be adjusted to account for the substantial devaluation of the Russian national currency in 2014-2018 (one should not ignore, however, that the national currencies of several other post-Soviet countries were also devalued during the period in question, and therefore it is necessary to approach each case of declining goods turnover on a strictly individual basis).

Based on analysis of the economic factors causing the CIS countries to drift toward multilateralism, one can conclude that post-Soviet countries often take a similar approach because of their aspiration toward a gradual geopolitical turn to the West and subsequent integration into the relevant political and economic structures (the North Atlantic Treaty Organization (NATO) and the European Union (EU), for instance), while retaining financial and resource support from Russia. Such a foreign policy course is not a novelty, and to varying degrees it has been typical of several post-Soviet countries (Ukraine and Georgia, for instance, and to a lesser extent, Moldova) since these countries celebrated their independence in 1991. However, in the context of a sharp aggravation of relations between Russia and the West, this phenomenon may well receive a new embodiment. To date, it is difficult to assess how efficient such a policy can be, but it will undoubtedly have influence on Russia's position in the former Soviet Union.

\section{Political Factors Making Multilateralism Attractive for the CIS Countries}

In close relationship with economic circumstances contributing to the decline of Russia's influence in the former Soviet Union, there is another group of objective factors that can be roughly attributed to politics. The gradual decline in Russia's role in the world economy and international commodity turnover pushes the CIS countries to diversify their own economic, and consequently, political courses. In this regard, multilateralism and the consequent need for a balanced foreign policy is a theme in many speeches and interviews of state representatives and political leaders in various countries of the former Soviet Union [Dorozhkin, 2012]. This is illustrated in statements by the presidents of Belarus, Kyrgyzstan and Kazakhstan. A.G. Lukashenko, president of the Republic of Belarus notes: "We have no other fate than to build our foreign policy as a multilateral one. Today we find ourselves in the epicenter of the Eurasian continent, this is our fate. We have no other way but to develop multilateralism" [RIA News, 2017]. A.S. Atambayev, former president of Kyrgyzstan observed: "One of the main tasks of foreign policy is to maintain a balance of interests among the major players in world politics. Consequently, for us, multilateralism 
is an independent and free choice of foreign policy, which is based, first of all, on the national interests of Kyrgyzstan and the welfare of the nation" [KRG, 2016]. N.A. Nazarbayev, president of Kazakhstan stated: "Due to its geopolitical position and economic potential, Kazakhstan has no right to confine itself to narrow regional problems. It would be incomprehensible not only to our multinational population, but to the whole world community either. The future of Kazakhstan lies both in Asia and in Europe, in the East and in the West. If we carry out such a policy, we will be able to exclude any manifestations of security threat to Kazakhstan. We will be able to improve favorable external conditions for economic and political reforms in our country" [Foreign-policy priorities of Kazakhstan, 2016].

These statements are essentially based on the same idea, even while articulated in somewhat different ways. Despite the absolute dissimilarity of the political, economic and social situations in Belarus, Kyrgyzstan and Kazakhstan, these CIS leaders perceive the choice for multilateralism as an objective political and economic need for their respective countries. The statement by N.A. Nazarbayev is particularly indicative in this regard, as it dates back to early December 1991 (that is, several weeks before the collapse of the USSR), and de facto was the political programme of Kazakhstan for the next few decades. In addition, it should be emphasized that although these statements do not directly articulate this idea, they nevertheless contain it implicitly: the leaders of post-Soviet countries view a gradual refusal or, at least, a departure from an exclusively pro-Russian focus in favour of a more multilateral approach as an advantageous foreign policy alternative. Therefore, the existence of objective political and economic interests in the CIS countries which do not always coincide with Russia's national interests and foreign policy needs should be pinpointed as being among the most important reasons for the pro-Russian forces to drift toward multilateralism, gradually reducing Russia's influence. Moreover, considering the objective nature of this factor, it is virtually impossible to resolve it in "manual control mode," that is, using purely subjective measures (for example, building up warm personal relationships with the leaders of the respective countries). On the contrary, in order to change the current situation for the better, it is necessary to use the widest range of measures designed to overcome the existing disagreements and coordinate joint efforts of Russia and the CIS countries to address key economic, political and humanitarian issues. This would ensure the convergence of the positions and national interests of Russia and the post-Soviet countries and minimize the threat of conflict or sharp deterioration of relations between the parties in the future.

\section{Historical, Social and Cultural Factors Impeding the Growth of Russia's Influence in the Former Soviet Union}

The collapse of the Soviet Union and the emergence of CIS countries gave a strong momentum to the rise of identity in the newly formed states, and quite often the search for ethnic and national identity carried out by the post-Soviet republics went in hand 
with a sharp rejection of their own past. Another serious contradiction is the fact that often members of the new national elites blamed the current social, economic and political problems peculiar to their countries on what they viewed as their colonial past, as well as on the policy of the Soviet Union and Russia as its legal successor. In particular, this trend was most visible from 1991-2017 in the Baltic states, Ukraine, Moldova and, to some extent, Georgia, while in the countries of Central Asia, Armenia and Azerbaijan this trend was rather less pronounced. Logically, the subjective perception of the Russian Federation as an actor more or less responsible for the current domestic and foreign political failures of the newly formed states, combined with objective problems in establishing a full-scale dialogue with Moscow on the widest range of fairly complex issues (relating, among other things, to such sensitive topics as the common past within the Russian Empire and the Soviet Union) had a negative effect on Russia's positions and the degree of influence in the former Soviet Union.

The decreasing relevance of pro-Russian special interest groups in several CIS countries has been discussed from an economic viewpoint. However, the trend toward multilateralism is driven by more than just trade and economic factors. The determining impact of historical and social factors as well manifested in a gradual divergence of the cultures of Russia and other post-Soviet countries after the collapse of the USSR, as well as in the declining role of the Russian language in the social and cultural life of CIS countries. To date, Russian has been given the status of an official language in only three states of the former Soviet Union, namely Belarus, Kazakhstan and Kyrgyzstan, while in the rest of the CIS countries its relevance is steadily decreasing. Moreover, the situation is aggravated by three important factors. First is the systematic reduction in the scope of the Russian language's use in both comprehensive and higher education, science, culture, television and radio broadcasting and in everyday life, evident in practically all the countries of the former Soviet Union. Second, we observe an almost complete absence of support for the Russian language in the former Soviet Union by federal authorities of the Russian Federation, as well as low efficiency of the Federal Agency for the Commonwealth of Independent States, compatriots living abroad and international humanitarian cooperation (Rossotrudnichestvo). Third is the transition of several CIS countries from the Cyrillic alphabet to Latin: a similar reform was carried out in Moldova in 1989, before the collapse of the Soviet Union. Uzbekistan and Turkmenistan shifted to the Latin script in 1993. Azerbaijan gradually rejected Cyrillic in 1992-2001. Finally, a similar reform was launched in Kazakhstan following a presidential decree dated 26 October 2017 [President of the Republic of Kazakhstan, 2018]. The decline in the size of the Russian-speaking diaspora and, consequently, the pro-Russian special interest groups in the CIS countries, is among the most important social and cultural preconditions for the decrease in the significance and the degree of Russia's influence in the former Soviet Union. 


\section{Political and Psychological (Subjective) Factors Reducing Russia's Political Efficiency in the Former Soviet Union}

The political and psychological factors contributing to the decline in Russia's influence in the former Soviet Union include an extensive range of personal and subjective reasons directly or potentially leading to a distorted assessment of the current status and specifics of Russia's bilateral relations with individual CIS countries. Political and psychological factors can be divided into three subcategories.

The first subcategory includes incorrect assessments by the Russian ruling class about the initial intentions and political preferences of certain forces in the former Soviet Union which position themselves as being pro-Russian. Often, representatives of the national elites of the CIS countries use pro-Russian rhetoric either as a populist tool aimed at attracting some of the electorate or to obtain immediate benefits from Russia. The most vivid example of this is the strategy of the Belarusian political class, interested in sourcing financial benefits for Belarus by positioning themselves as Russia's closest (or the only) reliable ally. Similarly, this subcategory includes the national elites of Armenia, who view the pro-Russian focus not as a value in itself, but rather as a tool helpful to ensure their own security and the most rapid resolution of the frozen Nagorno-Karabakh conflict in their favour. Another example of the Russian ruling class having a distorted view of the political aspirations originally attributed to the supposedly pro-Russian forces in the former Soviet Union is the situation that arose in 2003 after the Rose Revolution in Georgia. In particular, the Russian establishment initially considered Mikheil Saakashvili as a pro-Russian candidate, a lucrative alternative compared to Eduard Shevardnadze who tended to pursue a multilateral foreign policy course. Subsequent events clearly showed that the initial confidence in Mikheil Saakashvili's supposed pro-Russian focus was fundamentally wrong, and this later became one of the key reasons for the escalation of the South Ossetia conflict and the five-day Russia-Georgia war in August 2008.

Second, another problem of Russia's foreign policy in the former Soviet Union is a certain overemphasis on the concept of pro-Russian focus, that is, the identification of this term with the alleged readiness of certain political forces of CIS countries to make any possible concessions and compromise on the widest range of issues. In its reasoning, this viewpoint leads to the erroneous conclusion that finding a pro-Russian force in power in a given country of the former Soviet Union gives Moscow some kind of green light for any foreign policy actions it wants regarding the relevant subject. This causes serious damage to bilateral ties and, moreover, causes the previously loyal and completely pro-Russian forces to rapidly move toward multilateralism. Previously, a similar trend was typical for Russia-Ukraine relations during the presidencies of L.D. Kuchma (1994-2005) and V.F. Yanukovych (2010-2014). Today it is most prominent in Russia's interaction with Belarus and some other EAEU states (Armenia, Kyrgyzstan and partly, Kazakhstan) in whose regard Russia follows a logically mistaken thesis 
about the single-option nature of the pro-Russian course of these countries (which, for clarity, can be described with a well-known, though not so academic phrase, "there is no way around it"). Consequently, their readiness to make the most serious concessions in the economic, political and humanitarian spheres for the sake of preserving a long-term, close and privileged relationship with Russia is overestimated.

Third, the political and psychological aspect determining Russia's declining influence in the former Soviet Union is also driven by the significant overestimation by the Russian ruling class of the so-called subjective (personal) factor in relations with the CIS countries. This problem is most clearly manifested in three key areas. First, the Russian establishment erroneously equates good personal relations with the leaders/ members of the national elite or the ruling class of the CIS countries with their readiness to pursue an absolutely pro-Russian foreign policy. This misunderstands the fact that warm and friendly relations with the leader of a corresponding country does not imply any guarantee that the country's foreign policy will always unquestionably follow a course profitable for Russia. This kind of error is quite clearly manifested in relations with both counties of the former Soviet Union and countries of the far abroad (in this context, a notable example is the good personal relationship between President V. Putin of Russia and President D. Trump of the U.S., finding almost no correlation with the dynamics of bilateral relations, and in fact not helping to ease the current contradictions between the two countries).

The second way in which this problem manifests itself is in the tendency of the Russian establishment to make separate, often significant foreign policy decisions stemming from a relatively unpromising, subjective approach which is not based on a comprehensive rational analysis of a vast array of objective economic and political data. The authors believe that at all times this kind of subjectivistic, irrational approach to making key foreign policy decisions has been a direct consequence of excessive concentration of power in the hands of one leader or a small group of individuals. At the same time, one can note the following logical pattern: the stronger the concentration of power observed in a particular country, the greater the percentage of domestic and foreign policy decisions made on the basis of a subjectivistic approach. Ultimately this results in serious mistakes and miscalculations in the international arena.

The third way the problem appears is that the two above-mentioned tendencies result for the Russian ruling class in a significant underestimation of the urgent need for serious and systematic cooperation with the civil society structures, political opposition and non-governmental organizations (NGOs) in the post-Soviet countries. In other words, the overestimation of the role of pro-Russian (or mistakenly recognized as such) politicians of the CIS countries induces a rather risky foreign policy course aimed at interacting with only one of the important public groups of the respective country (again, using less academic terminology, such a foreign policy course can be metaphorically characterized as an "putting all of its eggs in one basket"). The result of using this approach in practice is often a situation when a power shift in a particular CIS country de facto leads 
to an almost complete loss of all existing ties with Russia and a subsequent escalation of the conflict. This was most clearly manifested in 2004 after the Orange Revolution in Ukraine and after the Euromaidan events in Kiev in late 2013 and early 2014.

\section{Regional Integration as a Mechanism to Support Russia's Influence in the Former Soviet Union}

In the historical context, the formation of the Russian Federation coincided with the need to counter the disintegrational trends in the former USSR which threatened to disrupt the existing economic, political, cultural and social ties between the former Soviet republics. Initially, the main mechanism designed to ensure the preservation of Russia's influence in the former Soviet Union was the CIS, which implied integration in all the above areas. However, subsequently, for a variety of reasons the Commonwealth demonstrated its low efficiency, motivating Russia to adapt its foreign policy course to some narrowly specialized formats of regional integration. In particular, the high-priority areas of interaction with the countries of the former Soviet Union, namely the trade and economic, and the military-political spheres, have found their practical implementation in the activities of the EAEU and the CSTO, respectively. The principal objective Russia pursues in carrying out its own activities in terms of these regional organizations is reduced to counteracting the negative factors causing its influence in the region to decline. Thus, the activities of integration associations in the former Soviet Union can be considered as a kind of counter-trend in relation to the effect of the factors described above.

In this context, a comprehensive assessment of the efficiency of regional integration instruments employed by Russia to strengthen its own positions in the former Soviet Union must answer the following question: how successfully does Russia's activity in regional organizations neutralize the factors causing the CIS countries to drift toward multilateralism? In view of its exceptional complexity and ambiguity, this question should be considered in a dialectical way.

On the one hand, there have been considerable advances made by the EAEU: elimination of customs restrictions and duties on a variety of commodity categories; greater freedom of movement for capital, services and labour within the integrative organization; registration of the legal framework for a common economic space; arrangement of a common market for certain product categories (pharmacological substances and medical products, for instance [EEC, 2017]; development of a programme liberalizing the electricity market, planned to take effect in 2019 [EAEU, 2016; EAEU 2018]; and the creation of a free trade zone between the EAEU and Vietnam (2016) [EEC, 2016], the People's Republic of China, Iran and Cuba (2018). The undeniable achievements of the EAEU increased Russia's influence in the former Soviet Union as their immediate consequence was the strengthening of trade, economic and social ties between Russia and its partners in the organization.

Similarly, certain success was also achieved in the military-technical and political spheres of cooperation, in particular, the signature of the CSTO Peacekeeping Agree- 
ment [CSTO, 2007a]; creation of the Joint Staff [CSTO, 2012] and the Emergency Management Coordination Council [CSTO, 2007b]; and the approval of the Action Plan for the Implementation of the Basic Guidelines for the Development of the Collective Security Emergency Response System [CSTO, 2014]. Some noteworthy results were achieved in ensuring information security of Russia and its partners in the organization. These accomplishments, despite their local and rather limited nature, had a certain positive impact on Russia's position in the former Soviet Union.

On the other hand, economic integration in terms of the EAEU has not yet become the basis (some kind of a driver) for acceleration and expansion of integration initiatives in other spheres. Moreover, the dynamics and pace of economic integration are affected by several negative factors, in particular, the remaining disagreements among the EAEU members on the list of categories of goods and services to be regulated by the legal and regulatory framework of the organization. As the latest example illustrating this trend, one can recall the discrepancy of the positions of Russia and Belarus regarding the supply of dairy products [Tut.by, 2018]. Similar problems arise from time to time in relations between other EAEU participants (for example, between Kazakhstan and Kyrgyzstan). Also, the members of the organization have not yet reached an agreement on the introduction of a single currency in mutual trade, and several countries directly oppose such an innovation even in the long term (consider Nursultan Nazarbayev's statement, "Earlier, there was one single currency, but now we don't have such a question on the agenda. There is nothing to be afraid of" [Altyn-orda, 2015]). This position is largely explained by the fears of several post-Soviet countries that a further integration of the economic sphere could make the EAEU members excessively dependent on Russia and, as a result, subsequently deprive them of their political independence.

Another problem of regional integration in the former Soviet Union is the actual inequality of the economic potentials of the participating countries which leads to a significant imbalance in the structure of mutual trade and to an excessive fiscal burden for many countries of the EAEU. According to Alisen Alisenov, PhD (economy), associate professor of the Department of Economics and Finance of the Russian Academy of National Economy and Public Service under the President of the Russian Federation, "In 2014, the fiscal burden to GDP was 34.5\% in Russia, 42.6\% in Belarus, and $26.4 \%$ in Kazakhstan. For the same period, the inflation indicators also display a significant difference: $11.4 \%$ in Russia, $16.2 \%$ in Belarus, and 7.0\% in Kazakhstan." [EAEU: Wishing for the Better, Having the Same Old Story] Therefore, the potential of free market instruments in terms of the EAEU has not been fulfilled, which has a negative bearing on the dynamics of strengthening Russia's influence in the former Soviet Union through regional integration mechanisms.

The following conclusion can be drawn based on the foregoing: the mechanisms of regional integration, due to the insufficient fulfillment of their potential and the existence of significant contradictions between individual countries, can only slightly offset the negative factors causing Russia's influence in the CIS region to decline. However, the current situation is not a dead end. The authors believe that with the proper politi- 
cal will of all the parties concerned, the role of regional integration associations may significantly increase in the long term, having a most positive effect on Russia's position in the former Soviet Union.

\section{Conclusion}

Having analyzed the factors causing the pro-Russian forces to drift toward multilateralism, and, consequently, causing Russia's influence in the former Soviet Union to decline, we are able to draw several conclusions. First, considering the current relations between the Russian Federation and the CIS countries, the dynamics of their bilateral and multilateral ties are largely determined by the broadest range of both objective and subjective factors. Unfortunately, in the near future this trend, paralleled with a gradual decline in the influence of pro-Russian forces in the former Soviet Union, is unlikely to stop and is even less likely to reverse. The authors believe this assumption to be a logical derivative from the thesis that the trend analyzed comprises numerous economic, political, historical, social and cultural, political and psychological factors that, mutually supplementing and reinforcing each other, acquire a significant synergetic effect.

Second, the mechanisms of regional integration in terms of the CIS, the CSTO and the EAEU could become effective instruments helping Russia preserve its influence in the former Soviet Union, but due to a variety of factors listed above this potential remains partly unfulfilled. Nevertheless, the foreign policy course to expand and deepen the integration processes in political, social and economic spheres may well become a fairly effective Russian response to the challenges threatening its positions in the CIS region.

Third, while the subjective factors having a negative bearing on the efficiency of Russia's policy in the former Soviet Union can potentially be minimized in a relatively short-term perspective, the situation regarding the objective factors, and especially those concerning Russia's declining role in the world economy and the reduction of its trade turnover with the CIS countries, is much more complicated, requiring a considerable amount of time to adjust the current dynamics. At the same time, the world political and economic situation will play a significant role in this process, and it is vital for Russia to exercise particular prudence, caution and delicacy in making key foreign policy decisions affecting its interests in the former Soviet Union. In the context of globalization and the buildup of numerous transnational challenges and threats, every foreign policy action of a country should be cleared of any emotional components and must rely on a thorough and painstaking analysis of the entire array of empirical and factual data available. The result of this approach should be absolute rationality and predictability of the foreign policy course of the corresponding actor.

Ultimately, the success of Russian foreign policy in the CIS region will largely depend on Moscow's restrained reaction to the sovereign choices of post-Soviet countries in the trading, economic, political, social, cultural and humanitarian spheres, as well as on the prompt minimization of the subjective factors discussed above, that is, 
on the total rejection of any irrational, not completely circumspect actions that could potentially damage the relationship between Russia and a significant part of the world community and, in particular, with its closest former USSR neighbours.

\section{References}

Altyn-orda (2015) Nazarbayev: EAEU Will Not Have a Single Currency, 14 December. Available at: https://www.altyn-orda.kz/nazarbaev-edinoj-valyuty-v-eaes-ne-budet (accessed 10 September 2018). (In Russian)

Arslanov R.A., Dzhangiryan V.G., Kurylev K.P., Petrovich-Belkin O.K. (2017) West European Countries and Their Foreign Policy in the Views of the Russian Liberals of Mid-to-Late Nineteenth Century. The International History Review, vol. 40, no 4, pp. 916-938. Available at: https://www.tandfonline.com/ doi/full/10.1080/07075332.2017.1350873 (accessed 25 February 2018).

Bazyleva S.P., Chernenko Y.F. (2016) Sotrudnichestvo Uzbekistana i Rossii kak stabiliziruyushchij faktor na evrazijskom prostranstve [Evolution of Relations Between Russia and Uzbekistan as a Stabilizing Factor in Eurasia]. Vestnik RUDN: International Relations, vol. 16, no 3, pp. 505-520. (In Russian)

Collective Security Treaty Organization (CSTO) (2007a) The Agreement on the Peacekeeping Activities of the Collective Security Treaty Organization, 6 October. Available at: http://base.spinform.ru/show doc.fwx? rgn=19059 (accessed 4 September 2018). (In Russian)

Collective Security Treaty Organization (CSTO) (2007b) The Resolution of the Collective Security Council of the Collective Security Treaty Organization on the Establishment of the Emergency Management Coordination Council of the Member States of the Collective Security Treaty Organization, 6 October. Available at: http://base.spinform.ru/show_doc.fwx?rgn=21503 (accessed 4 September 2018). (In Russian)

Collective Security Treaty Organization (CSTO) (2012) The Agreement on the Formation and Operation of the Forces and Assets of the Collective Security System of the Collective Security Treaty Organization, 14 June. Available at: http://docs.cntd.ru/document/902379431 (accessed 4 September 2018). (In Russian)

Collective Security Treaty Organization (CSTO) (2014) The Resolution of the Collective Security Council of the Collective Security Treaty Organization on the Action Plan for the Implementation of the Basic Guidelines for the Development of the Collective Security Emergency Response System of the Member States of the Collective Security Treaty Organization, 23 December. Available at: http://base.spinform. ru/show_doc.fwx?rgn=82006 (accessed 4 September 2018). (In Russian)

Degterev D., Vasilyuk I., Baum V. (2018) Parametry mnogovektornosti vneshnej politiki stran SNG: prikladnoj analiz [Multiplexity Parameters of the CIS Foreign Policy: Applied Analysis]. World Economy and International Relations, vol. 62, no 1, pp. 63-75. (In Russian)

Descalzi C.A.G. (2011) Russian Hegemony in the CIS Region: An Examination of Russian Influence and Variation in Consent and Dissent by CIS States to Regional Hierarchy. Available at: https://www.researchgate.net/publication/277072514_Russian_hegemony_in_the_CIS_region_an_examination_of_Russian_influence_and_of_variation_in_consent_and_dissent_by_CIS_states_to_regional_hierarchy (accessed 26 February 2018).

Dorozhkin Y.N. (2012) Aktual'nye problemy modernizacii politicheskoj sistemy Rossii [Contemporary Problems of the Russian Political System Modernization]. Vlast', no 10, pp. 10-13. (In Russian)

Eurasian Economic Commission (EEC) (2016) Free Trade Agreement Between the Eurasian Economic Union and its Member States, of the One Part, and the Socialist Republic of Viet Nam, of the Other Part. Available at: http://www.eurasiancommission.org/ru/act/trade/dotp/sogl_torg/Documents/ EAEU-VN_FTA.pdf (accessed 4 September 2018). 
Eurasian Economic Commission (EEC) (2017) A Common Market of Medicines Launched in the EAEU. Available at: http://www.eurasiancommission.org/ru/nae/news/Pages/5-05-2017.aspx (accessed 1 September 2018). (In Russian)

Eurasian Economic Union (EAEU) (2016) About the Program for the Formation of a Common Electric Power Market of the Eurasian Economic Union. Supreme Eurasian Economic Council Decision No 20, 29 December. Available at: http://docs.cntd.ru/document/456056118 (accessed 2 September 2018). (In Russian)

Eurasian Economic Union (EAEU) (2018) Treaty on the Eurasian Economic Union (as amended May 14, 2018) (edition effective since August 12, 2017). Available at: http://docs.cntd.ru/document/420205962 (accessed 2 September 2018). (In Russian)

Fedorchenko S.N. (2017) MVF i social'no-politicheskie processy na postsovetskom prostranstve [IMF and Socio-Political Processes in the Former Soviet Union]. Vestnik RUDN: International Relations, vol. 17, no 1, pp. 22-33. (In Russian)

Foreign Trade of Russia. Federal Tax Service of Russia Data. (In Russian) Available at: http://russiantrade.com (accessed 12 February 2018).

Galoyan N.G. (2015) Armyano-gruzinskie otnosheniya v kontekste regional'noj bezopasnosti na Yuzhnom Kavkaze [Armenia-Georgia Relations in the Context of Regional Security in Transcaucasia]. Vestnik RUDN: International Relations, vol. 15, no 4, pp. 120-131. (In Russian)

Gomart T. (2006) What is Russia's Influence in Post-Soviet Sphere? Available at: https://www.researchgate. net/publication/290650293_What_is_Russia\%27s_influence_in_Post-Soviet_sphere (accessed 28 February 2018).

KRG (2016) A. Atambayev: Multilateral Foreign Policy is Based on the National Interests of Kyrgyzstan. Available at: http://krg.rus4all.ru/exclusive/20160505/726618208.html (accessed 14 February 2018). (In Russian)

Kurylev K.P., Naryshkin V.S., Ozinkovskaya Y., Rakhimov K.Kh. (2016b) Evraziiskii ekonomicheskii soyuz vo vneshnepoliticheskoi strategii Rossii [EAEU in Russian Foreign Policy Strategy]. Vestnik RUDN: International Relations, vol. 16, no 1, pp. 75-86. (In Russian)

Kurylev K.P., Ngoyan A.L., Palasios K.E., Skudina O.V. (2016a) Neuregulirovannye konflikty na postsovetskom prostranstve $\mathrm{v}$ analize zapadnyh ehkspertno-analiticheskih centrov [Unsettled Conflicts in the Former Soviet Union in the Analysis of the Western Research Centres]. Vestnik RUDN: International Relations, vol. 16, no 3, pp. 482-493. (In Russian)

Lapkin V., Pantin V. (2016) Etnopoliticheskie konflikty na postsovetskom prostranstve: rol' vneshnepoliticheskih faktorov [Ethno-Political Conflicts in the Former Soviet Union: The Role of Foreign Policy Factors]. World Economy and International Relations, vol. 60, no 12, pp. 92-103. (In Russian)

Menon R., Rumer E.B. (2014) Conflict in Ukraine: The Unwinding of the Post-Cold War Order. Massachusetts: MIT Press.

Obolensky V. (2017) Otkrytost' nacional'nyh ekonomik: mir i Rossija [The Openness of National Economies: The World and Russia]. World Economy and International Relations, vol. 61, no 10, pp. 5-15. (In Russian)

President of the Republic of Kazakhstan (2018) Decree of the President of the Republic of Kazakhstan dated October 26, 2017 No 569 On Translation of Kazakh Alphabet from Cyrillic into Latin Script (as amended 19 February 2018). Available at: http://online.zakon.kz/Document/?doc_id=33613600\#pos=5;-103 (accessed 15 February 2018). (In Russian)

RIA News (2017) Lukashenko Asserts Belarusian Foreign Policy Shall be Multilateral. 3 February. Available at: https://ria.ru/world/20170203/1487110298.html (accessed 14 February 2018). (In Russian)

The Foreign Policy Concept of the Russian Federation (2016) Available at: http://www.mid.ru/en/ foreign_policy/official_documents/-/asset_publisher/CptICkB6BZ29/content/id/2542248 (accessed 28 September 2018). 
Tut.by (2018) EEC: Russian Restrictions on the Supply of Milk from Belarus Show Signs of a Violation of the EAEU Agreement, 6 June. Available at: https://news.tut.by/economics/595738.html?crnd=39719 (accessed 10 September 2018). (In Russian)

World Bank (c. a.). World Development Indicators. Available at: http://databank.worldbank.org/data/ reports.aspx? source $=$ world-development-indicators (accessed 12 February 2018).

Zagorsky A. (ed.) (2015) Russia and East Central Europe After the Cold War: A Fundamentally Transformed Concept. Available at: http://library.fes.de/pdf-files/id-moe/11384.pdf (accessed 25 February 2018). 


\title{
Проблема снижения влияния России на постсоветском пространстве: чем вызван дрейф государств СНГ в сторону многовекторности? ${ }^{1}$
}

\author{
О.К. Петрович-Белкин, А.А. Еремин, С.А. Бокерия
}

Петрович-Белкин Олег Константинович - к.и.н., старший преподаватель кафедры теории и истории международных отношений Российского университета дружбы народов; Российская Федерация, 117198, Москва, ул. Миклухо-Маклая, д. 10/2; E-mail: petrovioleg@yandex.ru

Еремин Аркадий Алексеевич - к.и.н., ассистент кафедры теории и истории международных отношений Российского университета дружбы народов; Российская Федерация, 117198, Москва, ул. МиклухоМаклая, д. 10/2; E-mail: eremin_aa@rudn.university

Бокерия Светлана Александровна - к.ю.н., доцент кафедры теории и истории международных отношений Российского университета дружбы народов; Российская Федерация, 117198, Москва, ул. МиклухоМаклая, д. 10/2; E-mail: petrovsvet@yandex.ru

Смомента распада Советского Союза проблема взаимоотношений России с государствами постсоветского пространства традиционно находится в центре внимания как академического, так и экспертного сообщества. Особую актуальность данный вопрос приобретает в контексте существенных изменений в мировой политике, вызванных стремительным ухудшением отношений между Россией и западными державами на фоне эскалации украинского кризиса. В настоящей статье предпринимается попытка выявить ключевые факторы экономического, политического и социального характера, негативным образом воздействующие на текущую динамику взаимоотношений между Российской Федерацией и странами СНГ и тем самым обуславливающие постепенное снижение влияния России на постсоветском пространстве.

Структура статьи определяется методологией исследования, состоящей в выявлении трех крупных комплексов факторов (объективных, объективно-субъективных и субъективных), препятствующих укреплению влияния России на постсоветском пространстве. При этом под объективными подразумеваются в первую очередь факторы экономического и политического характера; под смешанными, объективно-субъективными - социокультурные и исторические факторы; и, наконец, под субъективными - политико-психологические факторы, детерминирующие постепенное падение влияния России на постсоветском пространстве.

Опираясь на вышеуказанную методологию и обширный аналитический материал, авторы приходят к выводу, что отказ государств СНГ от пророссийского курса обусловлен не только (а в отдельных случаях - и не столько) объективной потребностью постсоветских государств в диверсификации своих политических и торгово-экономических связей, но и рядом субъективных социокультурных и политико-психологических факторов. Они подробно рассматриваются в тексте статьи. Кроме того, один из выводов по итогам исследования состоит в том, что большая часть субъективных факторов, негативно воздействующих на эффективность политики России на постсоветском пространстве, потенциально может быть существенно минимизирована в относительно краткосрочной перспективе. В то же время ряд объективных факторов - и в первую очередь касающихся падения роли России в мировой экономике и сокращения ее товарооборота с государствами СНГнапротив, носит достаточно долгосрочный характер, ввиду чего на исправление текущей динамики может потребоваться много времени.

Ключевые слова: внешняя политика; многовекторность; СНГ; постсоветское пространство; Россия; политическое влияние

Для цитирования: Петрович-Белкин О.К., Еремин А.А., Бокерия С.А. (2019) Проблема снижения влияния России на постсоветском пространстве: чем вызван дрейф государств СНГ в сторону многовекторности? // Вестник международных организаций. Т. 14. № 1. С. 94-112. DOI: 10.17323/1996-7845-2019-01-06

\footnotetext{
${ }^{1}$ Статья поступила в редакцию в мае 2018 г.
} 


\section{Источники}

Ассоциация содействия развитию внешнеэкономической деятельности (2015) ЕАЭС: хотели как лучше, получилось - как всегда. Режим доступа: http://np-srv.ru/news/964.html (дата обращения: 12.02.2018).

Базылева С.П., Черненко Е.Ф. (2016) Сотрудничество Узбекистана и России как стабилизирующий фактор на евразийском пространстве // Вестник Российского университета дружбы народов. Серия «Международные отношения». Т. 16. № 3. С. 505-520.

Внешняя торговля России (б. г.) Данные Федеральной налоговой службы (ФНС) РФ. Режим доступа: http://russian-trade.com/ (дата обращения: 12.02.2018).

Высший Евразийский экономический совет (2016) О Программе формирования общего электроэнергетического рынка Евразийского экономического союза. 26 декабря. Режим доступа: http://docs.canted.ru/document/456056118 (дата обращения: 02.09.2018).

Галоян Н.Г. (2015) Армяно-грузинские отношения в контексте региональной безопасности на Южном Кавказе // Вестник Российского университета дружбы народов. Серия «Международные отношения». Т. 15. № 4. С. 120-131.

Дегтерев Д., Василюк И., Баум В. (2018) Параметры многовекторности внешней политики стран СНГ: прикладной анализ // Мировая экономика и международные отношения. Т. 62. № 1. С. 63-75.

Дорожкин Ю.Н. (2012) Актуальные проблемы модернизации политической системы России // Власть. № 10. С. 10-13.

Евразийская экономическая комиссия (2017) В ЕАЭС стартует единый рынок лекарственных средств. Режим доступа: http://www.Eurasian commission.org/ru/nae/news/Pages/5-05-2017.aspx (дата обращения: 01.09.2018).

Евразийская экономическая комиссия (ЕЭК) (2016) Соглашение о свободной торговле между государствами - членами ЕАЭС и Социалистической Республикой Вьетнам. Режим доступа: http:// www.Eurasian commission.org/ru/act/trade/dotp/sogl_torg/Documents/EAEU-VN_FTA.pdf (дата обращения: 04.09.2018).

Евразийский экономический союз (ЕАЭС) (2018) Договор о Евразийском экономическом союзе (с изменениями на 14 мая 2018 г.). Режим доступа: http://docs.canted.ru/document/420205962 (дата обращения: 02.09.2018).

Концепция внешней политики Российской Федерации (утверждена Президентом Российской Федерации В.В. Путиным 30 ноября 2016 г.). (2016) Режим доступа: http://www.mid.run/foreign_policy/ news/-/asset_publisher/cKNonkJE02Bw/content/id/2542248 (дата обращения: 11.02.2018).

Курылев К.П., Нарышкин В.С., Озинковская Е., Рахимов К.Х. (2016) Евразийский экономический союз во внешнеполитической стратегии России // Вестник Российского университета дружбы народов. Серия «Международные отношения». Т. 16. № 1. С. 75-86.

Курылев К.П., Нгоян А.Л., Паласиос К.Э., Скудина О.В. (2016) Неурегулированные конфликты на постсоветском пространстве в анализе западных экспертно-аналитических центров // Вестник Российского университета дружбы народов. Серия «Международные отношения». Т. 16. № 3. С. 482493.

Лапкин В., Пантин В. (2016) Этнополитические конфликты на постсоветском пространстве: роль внешнеполитических факторов // Мировая экономика и международные отношения. Т. 60. № 12. C. $92-103$

Оболенский В. (2017) Открытость национальных экономик: мир и Россия // Мировая экономика и международные отношения. Т. 61. № 10. С. 5-15.

Организация Договора о коллективной безопасности (ОДКБ) (2007а) Соглашение Организации Договора о коллективной безопасности о миротворческой деятельности. 6 октября. Режим доступа: http://base.spin form.ru/show_doc.fwx?rgn=19059 (дата обращения: 04.09.2018).

Организация Договора о коллективной безопасности (ОДКБ) (2007b) Решение Совета коллективной безопасности Организации Договора о коллективной безопасности о создании Координационного совета по чрезвычайным ситуациям государств - членов Организации Договора о коллективной 
безопасности. 6 октября. Режим доступа: http://base.spin form.ru/show_doc.fwx?rgn=21503 (дата обрашения: 04.09.2018).

Организация Договора о коллективной безопасности (ОДКБ) (2012) Соглашение о порядке формирования и функционирования сил и средств системы коллективной безопасности Организации Договора о коллективной безопасности. 14 июня. Режим доступа: http://docs.canted.ru/document/902379431 (дата обращения: 04.09.2018).

Организация Договора о коллективной безопасности (ОДКБ) (2014) Решение Совета коллективной безопасности Организации Договора о коллективной безопасности о Плане мероприятий по реализации Основных направлений развития системы коллективного реагирования государств членов Организации Договора о коллективной безопасности на чрезвычайные ситуации. 23 декабря. Режим доступа: http://base.spin form.ru/show_doc.fwx?rgn=82006 (дата обращения: 04.09.2018).

Президент Республики Казахстан (2017) Указ Президента Республики Казахстан от 26 октября 2017 г. № 569 «О переводе алфавита казахского языка с кириллицы на латинскую графику» (с изменениями от 19 февраля 2018 г.). Режим доступа: http://online.salon.kz/Document/?doc_id=33613600\#pos=5;-103 (дата обращения: 15.02.2018).

РИА Новости (2017) Лукашенко заявил, что политика Белоруссии должна быть многовекторной. 3 февраля. Режим доступа: https://ria.run/world/20170203/1487110298.html (дата обращения: 14.02.2018).

Федорченко С.Н. (2017) МВФ и социально-политические процессы на постсоветском пространстве // Вестник Российского университета дружбы народов. Серия «Международные отношения». Т. 17. № 1. C. $22-33$.

Allyn-orda (2015) Назарбаев: Единой валюты в ЕАЭС не будет. Режим доступа: https://www.lateen-orda. kz/nazarbaev-edinoj-valyuty-v-eaes-ne-budet (дата обращения: 10.09.2018).

Arslanov R.A., Dzhangiryan V.G., Kurylev K.P. Petrovich-Belkin O.K. (2017) West European Countries and Their Foreign Policy in the Views of the Russian Liberals of Mid-to-Late Nineteenth Century // The International History Review. Режим доступа: https://www.tandfonline.com/doi/full/10.1080/07075332.2017.13508 73 (дата обращения: 25.02.2018).

Descaling C.A.G. (2011) Russian hegemony in the CIS region: an examination of Russian influence and of variation in consent and dissent by CIS states to regional hierarchy. Режим доступа: https://www.ResearchGate. net/publication/277072514_Russian_hegemony_in_the_CIS_region_an_examination_of_Russian_influence_and_of_variation_in_consent_and_dissent_by_CIS_states_to_regional_hierarchy (дата обрашения: 26.02.2018).

Gohmert T. (2006) What is Russia's influence in Post-Soviet sphere? Режим доступа: https://www.ResearchGate.net/publication/290650293_What_is_Russia\%27s_influence_in_Post-Soviet_sphere (дата обращения: 28.02.2018).

Ka inform (2010) Стратегия становления и развития Казахстана как суверенного государства верный курс, заданный Президентом Н. Назарбаевым. Режим доступа: http://inform.oz.:8080/arb/article/2299544 (дата обращения: 14.02.2018).

KRG (2016) Атамбаев А.: Многовекторность основана на национальных интересах страны. Режим доступа: http://keg.rus4all.ru/exclusive/20160505/726618208.html (дата обращения: 14.02.2018).

Menon R., Rumer E.B. (2014) Conflict in Ukraine: The Unwinding of the Post-Cold War Order. Massachusetts: The MIT Press.

The World Bank (с. a.) World Development Indicators. Режим доступа: http://databank.world bank.org/ data/reports.aspx?source=world-development-indicators (дата обращения: 12.02.2018).

Tut.by (2018) ЕЭК: Российские ограничения поставок молока из Беларуси имеют признаки нарушения договора о ЕАЭС. 6 июня. Режим доступа: https://news.tut.by/economics/595738.html?crud=39719 (дата обращения: 10.09.2018).

Zagorsky A. (2015) Russia and East Central Europe after the Cold War. Prague: Human Rights Publishers. Режим доступа: http://library.fes.de/pdf-files/id-moe/11384.pdf (дата обращения: 25.02.2018). 